\title{
PROBLEMS OF ENSURING COMPETITIVENESS FOR UKRAINIAN EXPORT ON THE WORLD FERROUS METALS MARKET
}

\author{
Dmytro Dovgan \\ Department of International Trade \\ Kyiv National Economic University named after Vadym Hetman \\ 54/1 Peremogy ave., Kyiv, Ukraine, 03057 \\ dmitriy.dovgan@gmail.com
}

\begin{abstract}
The author has analyzed theoretical and methodological foundations for international interaction between countries, namely the gravity models of J. Tinbergen and H. Linnemann.

The export competitiveness levels are divided into three levels: national, corporate and industrial. The author proposed to add the existing list of competitive export criteria by another - perspective. Since this criterion allows assessing the effectiveness of the national export development model, the availability and the possibility of maximizing the export potential, the effective use of available export potential.

The author has analyzed the development trends of the world ferrous metals market. In the framework of the above-mentioned analysis, the current state of domestic metallurgy was analyzed in the conditions of global market penetration and possible strategic prospects were identified.

Within the framework of gravity model improvement for ferrous metals market, the author offers to use as an indicator of the economy size - real GDP of partner countries; as the competitiveness factor - the Global Competitiveness Index of the country, and as the logistics costs factor - the average distance between the main ports of the partner countries and the index of economic freedom, which takes into account the volume of tariffs and non-tariffs barriers. Estimated model parameters allow identifying the most promising markets for the export of ferrous metals in order to be competitive in selected countries.

Learning the major players experience on the world ferrous metals market allowed concluding that diversification is one of the possible measures to overcome the economic problems of metallurgical enterprises by expanding market maneuver and increasing competitiveness.

It will provide more stable results, minimize losses in core business during crises and cyclical recessions. As competitive advantages are shifted to the new products, where the positions of Ukrainian manufacturers are shaky, it is essential to implement innovative development into the production process by adapting the experience and technologies of world leaders.
\end{abstract}

Keywords: competitiveness, export, gravity model, competitiveness criteria, competitiveness levels.

\section{Introduction}

The main trend of modern international trade is the intensification of the globalization for integration processes, which occurs under the influence of a large number of factors. At the moment, the socio-economic development of the country depends on trends and partnership on the global market. Status of the country in the international economic environment is determined by the type of its economy - industrial raw materials or industrial and technological.

Obtaining the status of a full-fledged player in the world market is possible only if the industry is competitive in its segment of the world market.

Mentioned above globalization trends necessitate the development of new strategies for the building competitive export at the appropriate levels: national, corporate and industrial.

\section{Analysis of the literature data and statement of the problem}

During the work, was used results of individual scientists and economists of the research topic, data of the World Steel Association, the World Economic Forum, World Trade Organization, Global Innovation Index, Index of Economic Freedom, statistical information, online resources.

Thus, Dutch economist [1] see competitiveness as the ability of the country's economy to maintain stable economic growth with full employment of an economically active population with- 
out the accumulation of country's external debt and without a continuous balance-of-payments deficit; Gurus of competition [2] - as a constant support of labor productivity at a higher level than competitors, due to continuous process of inventions and innovations implementation; [3] - as the ability of the country to produce, distribute goods and services in the international economy in the competitive struggle against goods and services produced in other countries in order to increase the living standards of the country's population; Experts of the Organization for Economic Cooperation and Development (OECD) - as a degree in which, under open market economy conditions, the country produces goods and services that have passed the test of international competition, while maintaining and increasing real national income [4].

In the work [5] determines the country's competitiveness to the relative productivity of factors used, which is reflected in the trade balance, exchange rate, relative prices and, in the long run, affects the welfare of the country.

The problem of export competitiveness is devoted to many works of both domestic and foreign scientists. But many of its aspects remain insufficiently disclosed and substantiated. There is still a certain terminological uncertainty, methodological inconsistency of author's positions, the methodological and instrumental development of export competitiveness measurement. The boundary between country, industry and corporation export competitiveness is highly arbitrary. The presence of competitive industries and productions in the state determines its economic growth and competitiveness. In this case, the competitiveness of the country's exports is a qualitative combination of the competitiveness of industries and corporations in combination with other factors.

\section{Aims and tasks of research}

The object of research is the process of building a competitive ferrous metals export.

The purpose of this work is to develop a competitive export model and its practical implementation by domestic entities on the world ferrous metals market.

To achieve this goal, the following main tasks were identified:

- to systematize theoretical approaches and to provide a definition of the essence of the concept of export competitiveness;

- to study the current state and main trends of the world ferrous metals market, to determine the degree of main criteria influence of export competitiveness for the steel industry;

- to define the prospects of domestic ferrous metallurgy on the world ferrous metals market;

- to develop a comprehensive methodological approach in assessing the attractiveness of the foreign market and the export competitiveness, taking into account the effect of the gravity model, which will include the most significant indicators for ensuring export competitiveness.

\section{Materials and methods of research}

To achieve a certain goal in the process of cognition of the essence and to define the characteristics of building export competitiveness was used the abstract-logical method. The economic-statistical method was used to establish the changing trends and export volumes dependence on the level of ferrous metals competitiveness.

In order to visualize the dynamics of the phenomena and processes studied, a graphical method was used. As an empirical model of international exchange, a gravity model was used to explain the actual volumes of ferrous metal export and regression analysis to determine the most suitable potential partner - the importer of domestic ferrous metals.

\section{Results}

The analysis of modern approaches to the definition of "export competitiveness" enables us to define it as the determined international competitiveness of products and companies with the ability of exporting country to adequately meet the needs of consumers in targeted foreign markets, responding to the criteria of sustainability, effectiveness and quality/innovation, integrity of competition.

The key event for the global steel industry in 2015 was the reduction of steel production in China, which was held for the first time since 1981. In comparison with 2014, the reduction in steel 
production in the PRC amounted to $2.3 \%$ or 19 million tons. However, China remains the leader in the ranking of the world's largest steelmakers, based on WorldSteel data. The share of China in global steel production results for 2015 even slightly increased - to $49.5 \%$ from $49.3 \%$ a year earlier [6]. The main reason for the decline in steel production in China has been a reduction in domestic demand due to slowing economic growth, the crisis on the real estate market, increased environmental standards and restricted access to credit for metallurgical companies (Table 1).

Table 1

Top 10 Steel Producing Countries in 2015

\begin{tabular}{|c|c|c|c|c|c|c|c|}
\hline Rank & $\begin{array}{c}\text { Rank in } \\
2014\end{array}$ & Country & $\begin{array}{l}\text { Production in } \\
\text { 2015, MT }\end{array}$ & $\begin{array}{c}\text { Change in \% } \\
\text { to } 2014\end{array}$ & $\begin{array}{l}\text { Produced } \\
\text { per capita }\end{array}$ & $\begin{array}{l}\text { Share in world } \\
\text { production, \% }\end{array}$ & $\begin{array}{l}\text { Steel production } \\
\text { export, } \mathrm{MT}\end{array}$ \\
\hline 1 & 1 & China & 803.83 & 97.70 & 584.20 & 49.53 & 92.91 \\
\hline 2 & 2 & Japan & 105.15 & 95.00 & 830.80 & 6.48 & 41.55 \\
\hline 3 & 4 & India & 89.58 & 102.60 & 68.30 & 5.52 & 10.32 \\
\hline 4 & 3 & USA & 78.92 & 89.50 & 245.30 & 4.86 & 11.96 \\
\hline 5 & 6 & Russia & 71.11 & 99.50 & 486.10 & 4.32 & 28.08 \\
\hline 6 & 5 & $\begin{array}{c}\text { Republic of } \\
\text { Korea }\end{array}$ & 69.67 & 97.40 & 1385.30 & 4.29 & 31.91 \\
\hline 7 & 7 & Germany & 42.68 & 99.40 & 528.90 & 2.63 & 24.76 \\
\hline 8 & 9 & Brazil & 33.25 & 98.10 & 159.90 & 2.05 & 9.77 \\
\hline 9 & 8 & Turkey & 31.55 & 92.70 & 401.00 & 1.94 & 16.02 \\
\hline 10 & 10 & Ukraine & 22.93 & 84.40 & 538.70 & 1.41 & 21.49 \\
\hline
\end{tabular}

Due to the reduction in domestic demand, the Chinese metallurgists actively increased its export, which led to increased competition in the world market, lower prices and reduced production in most countries.

Japan has maintained its second place in the rating, but reduced production by $5.0 \%$ due to reduced domestic demand and export supply. At the same time, the United States has dropped out of the top three and have cut production by more than 9 million tons a year. The decrease in production was mainly due to a reduction in domestic consumption of steel products from oil/gas and pipe-rolling plants after a sharp drop in oil prices.

The US has been displaced from third place by India, which is one of the few countries that have increased production in 2015. In the year, Indian steelmakers increased steel production by 2.3 million tons, the highest indicator in the world.

It should be noted that Ukraine has kept its place in the top ten, but the decline of steel production was the deepest, which is explained by the political and economic problems of the country.

The largest exporter of steel products (including semi-finished products) is China. On the second and third places - respectively, Japan and South Korea. Russia is the fourth largest exporter of steel products, slightly ahead of Germany, which is in fifth place.

World steel market in the medium term is optimistic and is set to increase metal production 1.1 times by 2020 in comparison with 2010 and in-kind steel market plans to produce 1,585 billion tons (average per year for the period 2016-2020) Even more steel market plans to produce in 2030 and an average for 2026-2030 is 2,181 billion tons will be produced, which is 1.5 times more than the initial index in the analyzed period. Compared with 2020, the world steel supply will increase by 1.37 times. In general, the dynamics of the world steel supply is positive, moreover, from 2016-2030. The growth rate of steel supply will increase annually. In particular, in 2025 the growth of production will be $13.62 \%$ compared to 2016-2020, the 2030 steel supply will increase 
by $21.09 \%$ compared to the previous period. The dynamics of the world steel supply from 2010 to 2020-2030 is presented in Fig. 1.

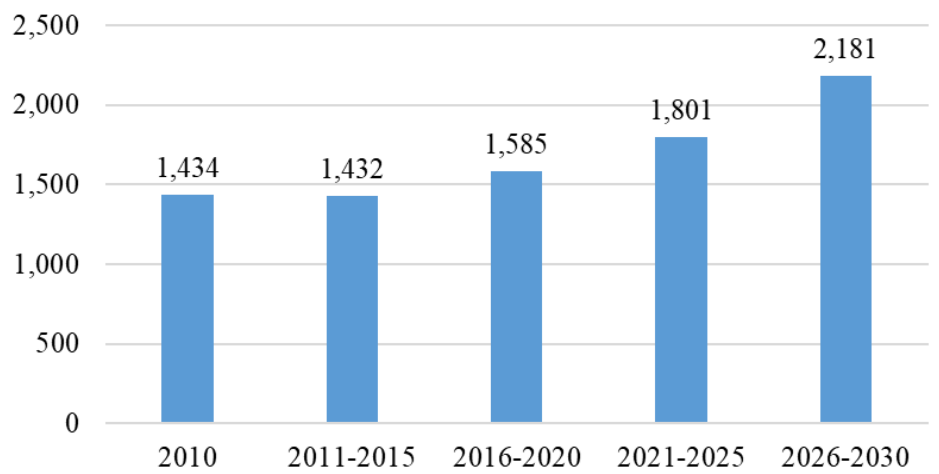

Fig. 1. Dynamics of the world steel supply from 2010 to 2030, MT

$$
\text { Source: [8] }
$$

The world steel demand in the medium and long term also plans to increase its performance and by 2030 it will increase 1.4 times compared to 2010, and the demand for steel on the world market will amount to 1,976 billion tons per year. By 2020 the demand for steel will be set at the level of 1,613 billion tons per year, and this will be 1.1 times more than the initial index in the analyzed period. The growth in demand for steel in the period 2016-2030 will increase, and in 2025 the growth in demand for steel will be $7.56 \%$ compared to the previous period (2016-2020), And by 2030 demand will increase by $13,89 \%$ in relation to the indicators of 2021-2025. The dynamics of world demand for steel from 2010 to 2020-2030 is presented in Fig. 2.

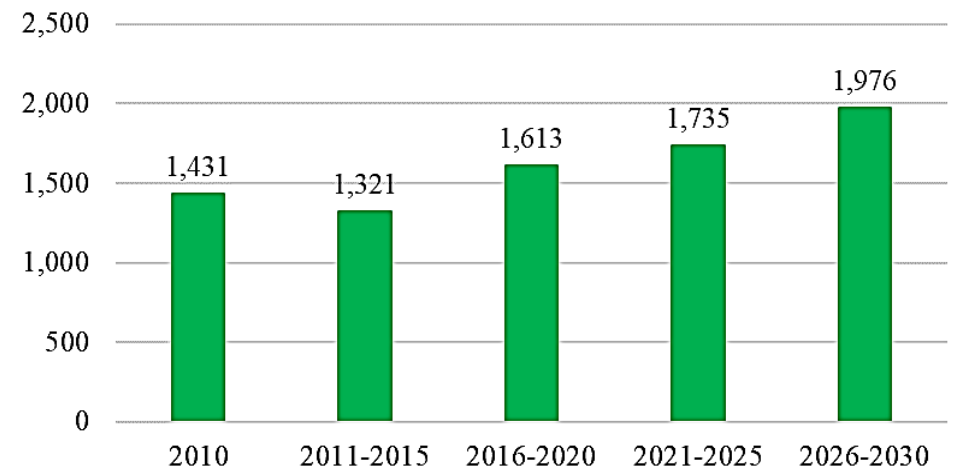

Fig. 2. Dynamics of world demand for steel from 2010 to 2030, MT Source: [8]

Thus, the world steel supply and world demand in the medium and long-term plans to increase its performance, while the growth of supply will outstrip the growth in demand for ferrous metals.

As for Ukraine, in the first 9 months of 2015, it was $20.4 \%$ less than in the same period of 2014, which was about 17,1 million tons of steel.

In the international economy, there is a tendency to reduce the volumes of steel production, but the pace of decline is negligible and slowing down. According to WorldSteel data, world steel production fell by $2.7 \%$ over the 8 months of 2015, while EU countries showing a slight increase in production by $0.1 \%$, after a $1.6 \%$ fall in production in July [7].

As a result of steel production in August 2015, Ukraine has remained the tenth largest steel producer in the world. The share of Ukraine in world steel production in August 2015 was 1.5 \% (it was higher by 0.1 percentage point than in July 2015, as shown in Fig. 3) [9]. 


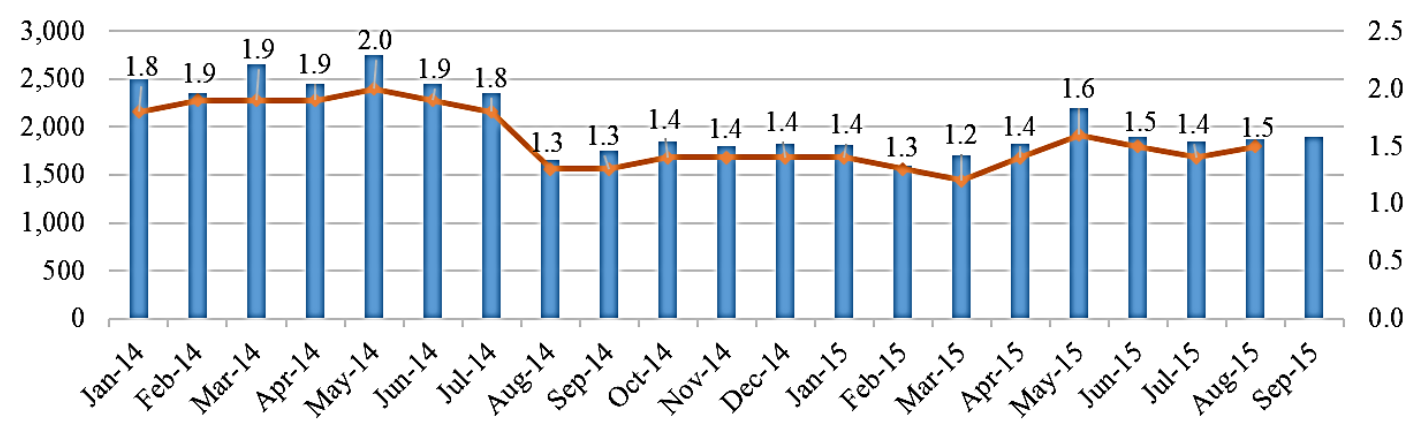

Steel production volume in Ukraine, MT $\quad$ Ukrainian share in world steel production, \%

Fig. 3. Ukraine's share in world steel production Source: World Steel Association

Reduction in rolled metal products production by $15 \%$ compared to 2014 led to a corresponding decrease in its exports.

The structure of export and import of rolled metal products is shown in Fig. 4 as can be seen from the structural export there were no significant structural changes. As before, more than $45 \%$ of export are semi-finished products.

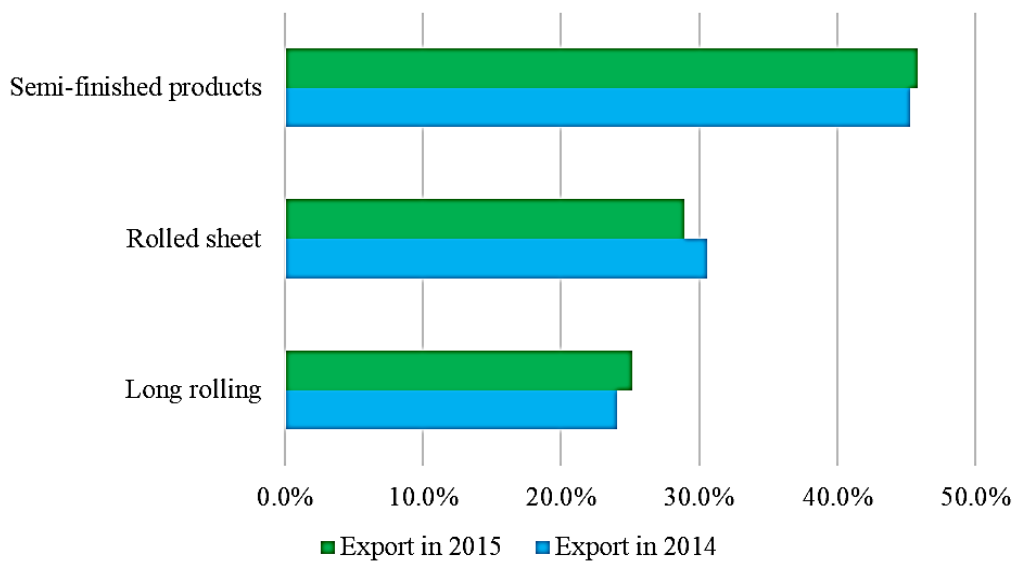

Fig. 4. Structure of export of rolled metal products

The share of ferrous metal products in the structure of export during 2008-2015 increased by only $2-5 \%$. The export of metallurgical products is raw material production. There is virtually no nomenclature of high-tech metal products: products of direct reduction of iron ores, sheets covered with the galvanic coating and electrolytic galvanizing, flat-rolled corrosion-resistant stainless steel [10].

About $7 \%$ of domestic metal export come from North Africa, as there is developing infrastructure projects, housing, and retail space.

As the competitive advantages of Ukraine on this market it should be noted:

- orientation on the export of semi-finished products necessary for the loading of local rolling mills, since new equipment and modern technologies are used;

- the relatively low price of products;

- the relative geographical proximity of markets, taking into account the access to ports of the Black and Azov seas.

Among the most significant constraints for the Ukrainian exporters in the North African metallurgical market are the following: cessing;

- in this region there is no demand for domestic ferrous metals with a high degree of pro-

- the domination of fast-growing Egyptian producers, whose metallurgical industry is rapidly developing. 
Ukrainian ferrous metal exporters have the ability to withstand and even expand their sales markets in Algeria, Libya, Tunisia and Morocco in connection with the implementation of infrastructure projects financed by the government of these countries, since their national metallurgy is only developing and they are more than $50 \%$ dependent on metal products import.

Globalization and internationalization of the world market acquire new forms and necessitate the development of new approaches, models and strategies for creating competitive advantages of the country, region, cluster, industry sector, company and product.

Theoretical models of international interaction do not always accurately explain the volume of trade or another type of international economic exchange between countries. Among empirical models of international interaction, the best known is gravity model, which enables accurately explain the actual volume of foreign trade or investment.

There are several variations of gravity models with the following indicators as the country population, the country area, the length of the border and the dummies variables in charge of social, political, climatic and other differences. Thus, the gravity models define the dependence of directional international trade flow according to intra-economic position parameters of exporting and the importing country.

The impact of these factors is estimated on the basis of actual trade size data between countries using regression analysis. Such parameters of a gravity model have the elasticity character and show the possible percentage increase in trade between countries if the corresponding factor increases by $1 \%$. For prediction trading flows between countries, the gravity models of J. Tinbergen and H. Linnmann are most often used [11, 12].

The model linking to the trade volume between two countries with the size of their economies and the distance between them was proposed by J. Tinbergen and had the following form:

$$
\log \mathrm{X}_{\mathrm{ij}}=\alpha_{0}+\alpha_{1} \log \mathrm{Y}_{\mathrm{i}}+\alpha_{2} \log \mathrm{Y}_{\mathrm{j}}+\alpha_{3} \log \mathrm{D}_{\mathrm{ij}}
$$

where $\mathrm{X}_{\mathrm{ij}}$ - export volume from one country to other depends on the GDP of the exporting country $Y_{i}$, which is a proxy variable for the volume of manufactured goods and such country is potentially able to offer to the international market as well as from the GDP of the importing country $Y_{j}$, which characterizes the volume of its domestic market.

The model of H. Linnemann is suggested that trade also depends on political and cultural factors, whether the countries are neighbors, on the resources availability, and so on. This method allows you to predict potential long-term trading flows.

H. Linnemann model has a more general view):

$$
\mathrm{X}_{\mathrm{ij}}=\alpha_{0}\left(\mathrm{Y}_{\mathrm{i}}\right)^{\mathrm{a}_{1}}\left(\mathrm{Y}_{\mathrm{j}}\right)^{\mathrm{a}_{2}}\left(\mathrm{~N}_{\mathrm{i}}\right)^{\mathrm{a}_{3}}\left(\mathrm{~N}_{\mathrm{j}}\right)^{\mathrm{a}_{4}}\left(\mathrm{D}_{\mathrm{ij}}\right)^{\mathrm{a}_{5}}\left(\mathrm{~A}_{\mathrm{ij}}\right)^{\mathrm{a}_{6}}\left(\mathrm{P}_{\mathrm{ij}}\right)^{\mathrm{a}_{7}}+\varepsilon
$$

where $X_{i j}$ - the cost of a trading flow from country $i$ to country $j ; Y_{i}, Y_{j}$ - indicators characterizing the nominal GDP of the relevant countries, in national currency; $\mathrm{D}_{\mathrm{ij}}$ - physical remoteness economic centers of $\mathrm{i}$ and $\mathrm{j}$ (in $\mathrm{km}$ ); $\mathrm{N}_{\mathrm{i}}, \mathrm{N}_{\mathrm{j}}$ - population in this country; $\mathrm{A}_{\mathrm{ij}}$ - any other factor which promotes or prevents trade (for example, the presence of boundaries or anti-dumping regime in one country); $\mathrm{P}_{\mathrm{ij}}$ - trade preferences that exist between the states (in the absence of preferential agreements $\mathrm{P}_{\mathrm{ij}}=1$, otherwise $\left.\mathrm{P}_{\mathrm{ij}}=2\right) ; \mathrm{a}_{1}, \mathrm{a}_{2}, \mathrm{a}_{3}, \mathrm{a}_{4}, \mathrm{a}_{5}, \mathrm{a}_{6}, \mathrm{a}_{7}$ - export elasticity coefficients according to GDP of exporting country, GDP of importing country, country's population i and j, the distance between the countries and other factors or trade preferences; $\mathrm{a}_{0}$ - absolute term of equation; $\varepsilon$ - random error.

The application of the gravity model allows to evaluate the main factors of exports competitiveness in international trade and identify the elements of a successful export-oriented strategy.

The main idea behind the approach of a gravity model in trade lies in the fact that the export volume from one country to another directly proportional to the economic size of these countries. Because the economic size of these countries determines, respectively, the exporting supply and demand, and inversely proportional to the distance between these countries, as delays in goods trading increase with the distance between partners [12]. 
In our proposed gravity model, as a measure of the size of the economy is used real GDP of countries (in US dollars), but as the distance between the exporter and the importer - the arithmetic distance between the key ports of the two countries.

Given the relationship between the indicators, we propose to build an equation that captures the essence of "gravity" for ferrous metals export:

$$
\begin{aligned}
& \ln \mathrm{X}_{\mathrm{ij}}=\mathrm{a}_{1} \ln \mathrm{Y}_{\mathrm{i}}+\mathrm{a}_{2} \ln \mathrm{Y}_{\mathrm{j}}++\mathrm{a}_{3} \ln \mathrm{Dis} \tan \mathrm{se}_{\mathrm{ij}}+\mathrm{a}_{4} \ln \mathrm{GK}_{\mathrm{i}}+\mathrm{a}_{15} \ln \mathrm{INK}_{\mathrm{j}} \\
& +\mathrm{a}_{6} \ln \mathrm{TF}_{\mathrm{ij}}+\mathrm{a}_{7} \ln \mathrm{TGET}_{\mathrm{ij}} \text {, }
\end{aligned}
$$

where Xij - export from country ${ }_{\mathrm{i}}$ to country $\mathrm{y}_{\mathrm{j}} \mathrm{Y}_{\mathrm{i}}$ and $\mathrm{Y}_{\mathrm{j}}-$ country GDP; Distance $_{\mathrm{ij}}$ - the distance

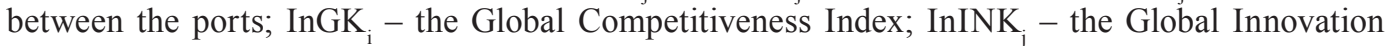
Index; $\operatorname{InTF}_{\mathrm{ij}}$ - Index of Economic Freedom; InTGET $\mathrm{ij}_{\mathrm{ij}}$ - the involvement index of the country in world trade.

In the improvement framework of the gravity model in ferrous metals trade between Ukraine and the EU countries, Ukraine and Africa countries, we propose to use as the production factor manufacturer's and exporter's country GDP.

Within the research on sales trends for ferrous metals on the world market we decided to use as a competitiveness factor - the Global Competitiveness Index, and as a factor of logistics costs the average distance between the main partner countries ports.

We propose to estimate the transaction costs factor taking into account the indices calculated by international organizations, which have a correlation with the Ukrainian ferrous metals export.

The next factor is the Index of Economic Freedom, which takes into account the volume of tariffs and non-tariffs barriers. Therefore, this index relevant for both the exporter and the importer, since it takes into account both export and import barriers. The growth of the Index of Economic Freedom for Ukraine shows the tendency to liberalize its trade relations.

All evaluations were conducted based on annual data from National Statistics Committee and international organizations. Calculated indicators allow identifying the most promising markets for ferrous metals export, which will be competitive in selected countries.

The conducted analysis of the structure of domestic ferrous metals export underlines that high-tech ferrous metals products have a small share of the world market, but there is a traceable growth trend.

For the modeling ferrous metals products flow, the total volume of commodity export groups 72 and 73 according to the United Nations classification over the last 10 years has been taken as the basis.

Within applying improved gravity model in research we used indicators of 8 countries: Estonia, Finland, Lithuania, Sweden, Nigeria, Senegal, Ethiopia, Kenya.

The regression analysis was conducted using spatial export data of Ukraine for 2005-2015 each pair of countries (for Ukraine and each importer country of domestic ferrous metals were built models for each year from the chosen time interval) $[6,10,13-15]$.

For further analysis of the results we have used the selected estimations of coefficients of exporting country GDP and coefficient of determination which is an indicator of an adequacy of the model.

The results of international trade analysis show a new economic reality, current position of Ukraine and prove the urgent need to find new horizons for the Ukrainian products. It is difficult for Ukrainian manufactures to enter European markets (today we see only raw material export to Europe), so it is worth focusing on Africa's markets, where the most promising partner for Ukraine is Kenya (Table 2).

The main features that make Kenya an important and promising partner for Ukraine is that Ukrainian products generally meet Kenyan needs and standards, prices are generally acceptable, and Kenya itself is increasingly taking on the role of the East African economic hub. 
Table 2

Parameters of the gravity model in the context of the partner countries

\begin{tabular}{ccccccccc}
\hline Indicators & Estonia & Finland & Lithuania & Sweden & Nigeria & Senegal & Ethiopia & Kenya \\
\hline $\mathrm{a}_{1}$ & 26.74 & 105.67 & 606.95 & 86.74 & $2,336.93$ & 81.77 & 268.03 & 22.70 \\
$\mathrm{a}_{2}$ & $-2,759.10$ & 5.65 & $-3,613.95$ & -38.39 & $-12,597$ & $-5,665.31$ & $5,086.61$ & $-3,185.67$ \\
$\mathrm{a}_{3}$ & 651.71 & -169.15 & $3,336.35$ & 84.70 & -129.89 & -47.73 & -34.07 & 21.40 \\
$\mathrm{a}_{4}$ & $4,381.46$ & $5,196.24$ & $-117,074.93$ & $7,997.82$ & $17,521.4$ & $15,614.26$ & $-68,370.29$ & $2,161.32$ \\
$\mathrm{a}_{5}$ & $-206,413.19$ & $25,222.40$ & $-434,310.19$ & 0.53 & $-160,284$ & $118,464.90$ & $166,421.03$ & $-85,978.89$ \\
$\mathrm{a}_{6}$ & $-2,101.32$ & $1,055.47$ & $2,139.28$ & $-2,913.53$ & $-6,168.76$ & -783.89 & $-8,423.10$ & $6,327.73$
\end{tabular}

By 2014 there was a steady expansion of the goods nomenclature and an increase in the bilateral trade volume. However, in 2014 due to objective processes in Ukrainian economy caused by the deterioration of the overall situation in the country due to Russian aggression, Ukrainian export of goods and services to Kenya has decreased and amounted to 126,430 thousand US dollars, which was $88.2 \%$ in relation to previous year [10].

Ukrainian export to Kenya in 2014 was dominated by grain $-63.1 \%$, ferrous metals $24.5 \%$ and fertilizers $-11.2 \%$.

Results graphical representation of the gravity model in international trade between Ukraine and Kenya indicate that the selected model has a probability of more than $94 \%$ and it allows us to conclude that the model we have chosen is effective.

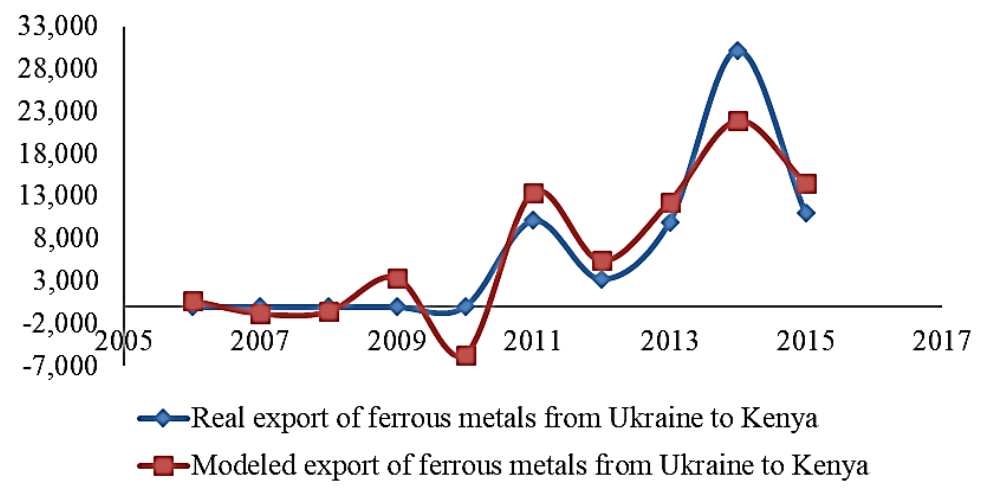

Fig. 5. Gravity model in ferrous metals trade between Ukraine and Kenya

In assessing the probability of this model for a selected country - Kenya, it should be noted that the proposed model is acceptable, since, it almost responsible to all criteria.

The imbalance in the world market of ferrous metals between surplus capacity and a decline in demand for steel products will take place for several years. When preserving these trends, domestic metallurgical enterprises should be oriented towards the intensification of competition even in the markets that are promising for them. Competitive advantages in this case, as international practice shows, can be obtained in two ways: due to the diversification of the product's structure, the new product types development and the reduction of prices for those product types that are already being manufactured and sold by the company [16].

Export diversification causes a change in the position of the country's export mix. Its foundation is the development strategy that includes activation of stimulating export products with added value through additional processing [17].

The degree of country diversification is currently considered as the dependence of the products quantity within its export mix.

In order to maintain its competitive position, Ukrainian metallurgical enterprises should revise funding in upgrading equipment and technology and focus on the production of the final products and its sale both on international and domestic markets. 
The experience of the major players on the global ferrous metals market shows that diversification is one of the possible ways to overcome the economic problems of enterprises by expanding market maneuver and increasing competitiveness.

Diversification allows to obtain more stable results, minimize losses in core business during crises and cyclical recessions. Since the competitive advantages are shifted to the new products, where the positions of domestic metallurgists are shaky, it is essential to implement innovative development into the production process by adapting the experience and technologies of world leaders.

\section{Discussion of the research results}

Traditional non-technological competitive advantages of domestic metallurgical enterprises are relatively low prices for steel products, soft environmental legislation, the presence of ores, favorable geographical location and specialization in the production of semi-finished products, but in the medium-term, they will take the forms of restrictions for the development of the metallurgical industry.

Over the past five years, the steel industry has been under the influence of serious structural shifts on the global ferrous metals market, which exacerbate the competitive struggle and challenge the domestic metallurgists to formulate and implement new development strategies.

In particular, the competitive position of Ukrainian metallurgy weakened in China, EU-28, and South-East Asia. However, the observed market expansion access new markets of the North African continent.

\section{Conclusions}

1. In order to increase the Ukrainian export competitiveness of ferrous metals on the world market, first of all, it is necessary to take into account the influence of its factors. The introduction of strategic measures to minimize the adverse effects of the global fermentation market overblown on the competitiveness of metallurgical enterprises will increase the competitiveness of its export in the face of increased competition in this market.

2. The export orientation of the steel industry reached a critical level, which, on the one hand, increases the risks of conjunctive nature, and on the other hand, the risks of the growth for the raw material dependence of the national economy on the foreign ferrous metals supply and products.

3. Among the priority tasks within the framework of scientific and practical research for domestic metallurgical enterprises, it is necessary to note the identification of still untapped competitive advantages on the foreign countries markets in terms of globalization and euro-integration. Particular attention will be paid to measures of increasing the competitiveness of science-intensive and technologically-advanced products of ferrous metallurgy and high added value production.

4. Identification of the potential competitive advantages of domestic ferrous metallurgy on the foreign market by forecasting and substantiating the scenarios of trade cooperation between Ukraine and foreign countries will allow identify commodity ferrous metals groups on the concrete foreign markets that have potential competitive advantages, but are not currently being used.

\section{References}

[1] Freeman, Ch., Lundvall, B.-A. (Eds.) (1988). Small Countries Facing the Technological Revolution. London: Pinter Publishers, 304.

[2] Porter, M. E. (1990) The Competitive Advantage of Nations. Harvard Business Review.

[3] Agosin, M. R. (2006). Trade and growth: why Asia grows faster than Latin America, 1. Inter-American Development Bank, Washington DC.

[4] OECD, TEP - The Technology/Economy Program. Technology and the Economy. The Key Relationships. OECD, Paris.

[5] Krugman, P. (1994). Competitiveness: A Dangerous Obsession. Foreign Affairs, 73 (2), 28. doi: $10.2307 / 20045917$ 
[6] Metallurhyya Kytaya: «ytohy tormozhenyya» (Chast’ I). Analytycheskaya hruppa «MetalTorg. Ru» (2008). Available at: http://www.metaltorg.ru/analytics/black?id=400

[7] Steel Statistical Yearbook (2015) World Steel Association. Available at: https://www.worldsteel org/media-centre/press-releases/2015/worldsteel-2015-steel-statistical-yearbook-now-available-online.html

[8] Organization for Economic Cooperation and Development. Steelmaking Raw Materials: Market and Policy Developments. Available at: http://www.oecd.org/sti/ind/steelmaking-raw-materials.pdf li-v-ukrayini

[9] Vyrobnytstvo stali v Ukraini. Available at: http://edtslub.tsom.ua/analityka/vyrobnytstvo-sta-

[10] Struktura zovnishn'oyi torhivli tovaramy Ukrayiny z Respublikoyu Keniya u 2007-2015 rokakh. Available at: http://compi.com.ua/stan-torgoveleno-ekonomichnogo-spivrobitnictva-mij-ukrayinoyu. html?page $=2$

[11] Leibenstein, H., Tinbergen, J. (1966). Shaping the World Economy: Suggestions for an International Economic Policy. The Economic Journal, 76 (301), 92. doi: 10.2307/2229041

[12] Bergstrand, J. H., Egger, P. (2013). Gravity Equations and Economic Frictions in the World Economy. Available at: https://www3.nd.edu/ jbergstr/Working_Papers/Gravity_Survey.pdf

[13] Sergienko, O. A. (2012). Complex analysis of branch trends of metallurgical enterprises' competitiveness. Visnyk ekonomiky transportu i promyslovosti, 38, 214-223.

[14] Kod dostupa k Evrope (2008). Vneshnyaya torhovlya. Ekspert Ukraina, 5. Available at: http:// www.expert.ua/articles/7/0/5012/

[15] Eksport chornykh metaliv za krayinamy svitu (2016). Available at: http://www.ukrstat.gov.ua/ operativ/operativ2016/zd/e_iovt/arh_iovt2016.htm

[16] Dovhan, D. A. (2015). Dyversyfikatsiia ukrainskoho eksportu chornykh metaliv ta ekonomichne zrostannia. Naukovyi visnyk Uzhhorodskoho natsionalnoho universytetu, 3, 114-117. http://visnyketsonom. uzhnu.uz.ua/archive/3_2015ua/29.pdf

[17] Mazur, V. L. (2010). Metalurhiia Ukrainy: stan, konkurentospromozhnist, perspektyvy. Metallurhycheskaia hornorudnaia promyishlennost, 2, 10-14. 